\title{
Desapropriação para Fins de Reforma Agrária nos Casos de Descumprimento das Funçōes Social, Ambiental e Trabalhista
}

Disappropriation for Land Reform Purposes in Cases of Noncompliance of Social, Ambiental and Labor Functions

Maria Isabel Tancredo ${ }^{1}$

Recebido em 01/02/2016 e aceito em 14/04/2016.

Resumo: $O$ artigo debate a possibilidade de, em casos de descumprimento da função social da propriedade em seus requisitos trabaIhistas e socioambiental, haver a desapropriação da propriedade para fins de reforma agrária. Partindo da desconstrução da noção de propriedade como direito fundamental absoluto, diante da necessidade de cumprimento de sua função social, visa debater os requisitos para cumprimento da função social enquanto simultâneos. Sendo assim, questiona a produtividade como elemento central no debate da desapropriação para fins de reforma agrária, por conta da vedação do artigo 185, II, Constituição Federal. Uma vez que os requisitos devem ser cumpridos de forma simultânea, a propriedade que não cumpre qualquer um dos requisitos listados no artigo 186, Constituição Federal, é passível de desapropriação.

Palavras-chave: reforma agrária; poder judiciário; desapropriação; função social; propriedade.

1 Pontifícia Universidade Católica do Rio de Janeiro (PUC-RIO). E-mail: bebeltancredo@ gmail.com 
Abstract: The article debates the possibility of disappropriation for land reform purposes in cases of non-compliance of property's social function in its ambiental, social and labor requisites. Deconstructing the notion of property as an absolut fundamental right, given the need of compliance of its social function, aims to discuss the requisits of compliance of social function of property as simultaneous. Therefore, questions the produtivity as the central question in the debate of disappropriation for land reform purposes, because of the prohibition of the article 185, II, Federal Constitution. Once the requisits must be respected simultaneously, the property that does not compliance either one of the requisits listed on the article 186, Federal Constitution, is subject to disappropriation.

Keywords: land reform; judicial power; disappropriation; social function; property.

\section{INTRODUÇÃO}

O debate sobre a Reforma Agrária passou por diversos momentos no Brasil, desde o período anterior a Ditadura Militar até as discussões atuais. Se no momento anterior à Ditadura Militar havia grande efervescência no que tange ao debate sobre o campo, a repressão dos chamados "anos de chumbo" foi responsável pelo silenciamento da questão, trazendo consequências perceptíveis até os dias atuais.

A concentração de terras no Brasil é um problema antigo, mas no momento pré-Ditadura Militar o tema da Reforma Agrária alcançou seu ápice de debate no país. Diversos projetos de Reforma Agrária eram propostos, com diferentes pressupostos e objetivos. Todavia, havia o entendimento comum da necessidade de alteração da estrutura fundiária brasileira de forma a garantir maior desenvolvimento econômico, na compreensão de alguns, ou diminuir as desigualdades sociais e regionais, na concepção de outros.

Findo o período militar, a repressão no campo e o silenciamento dos efervescentes debates anteriores sobre a Reforma Agrária tornaram 
as discussões e pesquisas acadêmicas sobre a questão fundiária cada vez mais raras. Na realidade econômica brasileira, as empresas rurais vieram para ficar, desenvolvendo-se no grande e forte agronegócio percebido hoje no país. Nesse sentido, a política realizada na Ditadura Militar se mantém no período democrático, preservando a concentração fundiária. O sentido de continuidade das empresas no campo era evidente em 1984, quando da publicação do livro "A Militarização da Questão Agrária no Brasil” (MARTINS, 1984), e se mantém presente atualmente. O autor destacou: "[a] instalação de grandes empresas no campo estava e está baseada no pressuposto da expropriação e da expulsão dos trabalhadores rurais para a cidade, na concentração da propriedade da terra e no aumento progressivo da eficiência econômica e da produtividade pecuária."

Ao mesmo tempo em que há um desenvolvimento das políticas estatais voltadas à Reforma Agrária, os movimentos sociais também se transformaram ao longo do tempo. Enquanto alguns movimentos de luta pela terra utilizavam amplamente a linguagem do direito, especialmente o Estatuto da Terra, o Movimento dos Trabalhadores Rurais Sem Terra (MST) se organiza na redemocratização. Questionando o modelo utilizado pela Confederação Nacional dos Trabalhadores na Agricultura (CONTAG), o MST defende a perspectiva da ação direta, com as ocupações. É fundamental a participação desses movimentos, pressionando o Instituto Nacional de Colonização e Reforma Agrária (INCRA), autarquia federal responsável pela implementação da Reforma Agrária no Brasil, através das ocupações, marchas e reuniões de negociação.

A participação dos movimentos sociais na produção de novos significados interpretativos para os instrumentos normativos se mostra essencial para desconstrução do pensamento hegemônico de defesa da propriedade e solidariedade com proprietários, estruturas de naturalização do direito de propriedade enquanto absoluto que perderam o sentido com a nova constituição.

Desafiando o conceito ultrapassado de direito de propriedade enquanto natural e absoluto, o presente artigo se volta ao estudo da função social da propriedade e sua importância para garantir e efetivar a justiça distributiva no campo. 
Embora o agronegócio seja apresentado como a solução para a problemática do campo, dados do Atlas da Terra Brasil 2015 mostram que a figura do latifúndio improdutivo ainda é extremamente presente no país. Há 175,9 milhões de hectares improdutivos no Brasil.

Outra face cruel e emblemática do campo brasileiro é o trabalho escravo. Pesquisa da Comissão Pastoral da Terra (CPT) mostra que, de 2003 a 2013, 42.476 trabalhadores em condições análogas à escravidão foram libertados no Brasil tanto na cidade quanto no campo, $27 \%$ deles da pecuária e $23 \%$ da cana de açúcar².

Em pesquisa recente divulgada pela $\mathrm{Globo}^{3}$, o instituto de pesquisa Imazon, revelou que entre agosto de 2014 e fevereiro de 2015 foram derrubados 1700 quilômetros quadrados de floresta nativa na Amazônia. Os dados apresentam um aumento de $215 \%$ no desmatamento em comparação ao período anterior. O desmatamento na região amazônica é alvo de grande destaque da imprensa nacional, mas muitas outras regiões brasileiras também são afetadas por práticas de violação a legislação ambiental. Trata-se de grave problema que assola propriedades de todo o Brasil.

Tais reflexões revelam como o desrespeito e violações de direitos trabalhistas e legislação ambiental não podem ser tratados como problemas secundários. Nesse sentido, a presente pesquisa se mostra profundamente relevante por apresentar soluções possíveis para a concentração fundiária, a partir da efetivação de normas constitucionais. O tema estudado refere-se à possibilidade de desapropriação-sanção de propriedades que, embora produtivas, descumprem a função social ambiental e trabalhista.

Os objetivos da pesquisa foram investigar a interpretação doutrinária e jurisprudencial atual acerca da simultaneidade dos requisitos de cumprimento da função social da propriedade. Consequentemente,

2 O GLOBO. "Libertações por trabalho escravo na área urbana superam as do campo". Disponível em: <http://g1.globo.com/brasil/noticia/2014/02/libertacoes-por-trabalhoescravo-na-area-urbana-superam-do-campo.html>. Acesso em 08/04/2016.

3 G1 - GLOBO. "Desmatamento na Amazônia cresce 215\% em um ano, segundo o Imazon". Disponível em: <http://g1.globo.com/jornal-nacional/noticia/2015/03/desmatamento-naamazonia-cresce-215-em-um-ano-segundo-o-imazon.html >. Acesso em 08/04/2016. 
objetivou-se avaliar a possibilidade de desapropriação de terras consideradas produtivas pelo critério exclusivamente economicista, mas que tiveram sua produção baseada na violação de legislação ambiental e trabalhista.

Buscou-se observar qual era o pensamento da doutrina constitucional quanto a simultaneidade dos requisitos e qual era a aplicação feita pelo Poder Judiciário, na tentativa de compreender a participação do referido poder na implementação da política de Reforma Agrária. A partir da compreensão da simultaneidade dos requisitos de cumprimento da função social da propriedade, o grupo intentou avaliar as possibilidades reais e práticas que são consequência dessa interpretação.

A metodologia utilizada na pesquisa se divide em três métodos de pesquisa. O primeiro deles foi um estudo bibliográfico interdisciplinar da questão agrária brasileira. Inicialmente, em grupo de pesquisa na Pontifícia Universidade Católica do Rio de Janeiro, em projeto denominado "O Poder Judiciário Fluminense e a Reforma Agrária", com orientação da Professora Mariana Trotta, analisamos textos da sociologia e história sobre a conjuntura agrária no Brasil, visando compreender a complexidade da questão. Em seguida, foram lidos textos sobre os embates constituintes que geraram o texto cristalizado atualmente pela Constituição de 1988 de forma a compreender o texto constitucional enquanto resultado de lutas políticas. Após essa reflexão, foi feito estudo bibliográfico dos instrumentos normativos disponíveis para a implementação da Reforma Agrária em conjunto com leitura de textos sociológicos e históricos de cada período, objetivando compreender a conjuntura geradora do texto legal. Por fim, analisamos bibliografia referente ao tema da desapropriação para fins de reforma agrária nos casos de descumprimento da função social ambiental e trabalhista da propriedade.

O segundo método de pesquisa utilizado foram os estudos de caso da Fazenda Cabaceiras, no Pará, e da Fazenda Nova Alegria, em Minas Gerais. Os processos de desapropriação das referidas terras foram analisados pelo grupo, visando compreender os atos dos processos desapropriatórios, os conteúdos das decisões judicias e os 
argumentos utilizados pelas partes. Foram escolhidos tais casos por serem emblemáticos enquanto primeiras oportunidades de desapropriação-sanção por descumprimento da função trabalhista, no caso da Fazenda Cabaceiras, e ambiental, na Fazenda Nova Alegria.

O terceiro e último método utilizado para a realização da pesquisa foi a pesquisa-ação, caracterizada pela troca entre o aluno e as comunidades e movimentos sociais. Visando dar aos alunos de Direito a oportunidade de conhecer a realidade debatida na Universidade, foram feitas vivências no Assentamento Roseli Nunes, em Piraí, no Rio de Janeiro. As vivências foram promovidas pelo projeto "Direitos em Movimento: Territórios e Comunidades", coordenado pelo Professor Adriano Pilatti e Mariana Trotta como parte do Núcleo de Estudos Constitucionais da PUC-Rio.

Foram realizadas duas visitas de três dias cada, uma em 2013 e outra em 2014, ao assentamento. Durante a vivência, os alunos ficaram hospedados em casas de assentados, onde puderam conhecer os desafios das famílias e as transformações vividas após a conquista da terra. Os alunos do grupo de pesquisa foram orientados a perceber os desafios da realidade rural e sua relação com a administração pública, principalmente o Poder Judiciário. Assim, foi possível traçar um conhecimento maior acerca da relação do movimento social e das famílias assentadas com o Poder Judiciário da região, hospitais, meios de transporte e escola, desenvolvendo um senso crítico sobre os desafios após a conquista da terra.

A experiência foi fundamental para a compreensão da realidade do campo e, no caso do Roseli Nunes, dos problemas ambientais herdados pelos assentados por conta da exploração de Eucalipto realizada em parte da fazenda, desapropriada por ser manifestamente improdutiva.

Importante salientar que o método pesquisa-ação foi pensado para o estabelecimento de uma relação de trocas entre os pesquisadores e as famílias. Nesse sentido, aprendemos e observamos diversos elementos fundamentais para o desenvolvimento da pesquisa, como as condições da propriedade após sua desapropriação após sofrer inúmeros danos ambientais, as relações de trabalho na região e os 
problemas de administração pública para garantir acesso à educação, saúde e ao poder judiciário. Ao mesmo tempo, foi prioridade o retorno ao Assentamento Roseli Nunes para a realização de debates e pequenas apresentações sobre a temática de Direito Ambiental. Valorizando, assim, não só o aprendizado que tivemos enquanto pesquisadores, como também a busca por retornar com esse trabalho para a comunidade rural.

\section{A REFORMA AGRÁRIA NO PERÍODO MILITAR}

O acalorado debate e as propostas de Reforma Agrária culminaram no anúncio das Reformas de Base de João Goulart no dia 13 de março de 1964, com a assinatura do Decreto $n^{\circ}$. 53.700/63 dando à Superintendência de Política Agrária poderes para iniciar a desapropriação de terras. Foi um dos principais estopins para o golpe militar no fim do mês seguinte.

Esperava-se do governo militar uma política de afastamento do debate da busca pela desconcentração fundiária, visto como tema típico dos seguimentos de esquerda, classificados como comunistas e execrados pelo regime no contexto de guerra fria. Porém, ainda no primeiro ano do regime, em novembro de 1964, foi promulgado o Estatuto da Terra. Já no primeiro artigo, é possível perceber a concepção de Reforma Agrária trazida pelos militares: a conjunção da chamada "justiça social" com a urgência do desenvolvimento econômico, calcado no "aumento da produtividade".

O governo militar tinha como objetivo realizar o desenvolvimento do campo brasileiro a partir da instalação das chamadas "empresas rurais", vistas por muitos como a origem do agronegócio brasileiro. Nesse sentido, José de Souza Martins defende que o Estatuto da Terra não era voltado para o camponês, mas sim para o empresário. Segundo o autor "O destinatário do Estatuto é o empresário, o produtor dotado de espírito capitalista, que organiza a sua atividade econômica segundo os critérios da racionalidade do capital" (MARTINS, 1984). 
Compartilha do mesmo pensamento Regina Bruno, ao criticar a falta de definição exata do conceito. A empresa rural funcionava como uma proteção aos latifúndios com uma certa produção, chamados "razoavelmente explorados", uma vez que concedia imunidade face a desapropriação. A autora destaca que "Nesse sentido, a mal definida empresa rural, isenta de desapropriação, seria a brecha escapatória para a continuidade do latifúndio" (BRUNO, 1997).

Era também tônica do governo militar a lógica de "ocupação dos espaços vazios". Buscava-se "colonizar" as áreas consideradas improdutivas e não ocupadas, a partir do fomento da instalação das empresas rurais principalmente na região norte do país. O projeto, porém, não previu a explosão de conflitos rurais que começaram a se instaurar nas áreas que, afinal, já eram ocupadas por populações tradicionais e camponeses.

O objetivo do governo militar era a diminuição dos conflitos agrários em conjunto com o desenvolvimento capitalista do campo, mas sempre enfrentou a questão agrária como uma questão técnica, buscando afastar a política dos embates sobre o tema. Para isso, a repressão no campo chegou cedo. Já em 1964 foram registrados no campo uma série de desaparecimentos e assassinatos de ativistas e advogados rurais.

A política militar de expansão da empresa capitalista no campo, principalmente a política de incentivos ficais aos grandes empresários rurais, em conluio com a forte repressão e esvaziamento político no meio rural e a política de colonização, gerou um aumento expressivo das tensões sociais no campo. A região nordeste do país, em 1971 e 1972, era responsável por $19.4 \%$ dos conflitos fundiários do Brasil e passou a representar, em 1975 e 1976, 70.2\% (RODRIGUES e SILVA, 1977).

O período militar no Brasil deixou grandes sequelas no campo e na institucionalização da Reforma Agrária. Se no início foram garantidos diversos institutos normativos que permitiam a realização de uma ampla reforma agrária no país (embora não tenham sido aplicados de forma efetiva) e a organização do Poder Executivo nesse sentido, o 
governo Médici, a partir de 1973, foi um período crítico para a democratização do acesso à terra. O novo Presidente enfatizou a repressão no campo, desmantelou a estrutura do Poder Executivo para a Reforma Agrária e voltou os ministérios da área para ministros favoráveis ao projeto das empresas rurais.

\section{FUNÇÃO SOCIAL DA PROPRIEDADE E A SIMULTANEIDADE DOS REQUISITOS NA CONSTITUIÇÃO FEDERAL}

No título VII da Constituição Federal (“Da Ordem Econômica e Financeira”), encontramos o Capítulo III ("Da Política Agrícola e Fundiária e da Reforma Agrária"). No referido capítulo estão fixados os artigos 184 a 191, frutos do trabalho da Sub-Comissão VI-C e Comissão VI da Assembleia Constituinte de 1987-1988, após passarem pela Comissão de Sistematização e voto em Assembleia Geral ${ }^{4}$. Os artigos cristalizados na Constituição Federal foram alvo de acalorados debates com a singular influência de fatores externos importantes, tais como a União Democrática Ruralista (UDR), o Poder Executivo (representado pelo Presidente José Sarney) e organizações de trabalhadores sem terra (MST e CONTAG).

Pouco se pode dizer sobre a participação da Sub-Comissão VI no texto efetivamente cristalizado na Magna Carta, uma vez que os embates entre progressistas e conservadores permitiram a aprovação de apenas dois artigos. O pequeno projeto aprovado foi encaminhado para a Comissão VI, com ampla maioria conservadora, garantindo a vitória da emenda que continha as propostas menos favoráveis ao avanço da Reforma Agrária. A partir da Comissão de Sistematização, com o enfrentamento do chamado "Buraco Negro" e a formação do bloco "Centrão", alguns avanços foram feitos, mas o texto final do capítulo não foi considerado uma vitória dos progressistas. Os temas de maior controvérsia na Assembleia Nacional Constituinte relacionados à Reforma Agrária foram a limitação do tamanho das

$4 \quad$ Ver em: Pilatti (2008). 
propriedades, a possibilidade de desapropriação de terras produtivas, a imissão do INCRA na posse do imóvel e o pagamento da indenização pela desapropriação.

Mesmo com a resistência na definição de função social da propriedade, a Constituição Federal de 1988 manteve esse elemento fundamental ao estudo do direito à propriedade, existente expressamente desde a Constituição de 1946. A partir daquele momento não seria a propriedade considerada um direito fundamental absoluto ou natural (SILVA, 2014), mas vinculado à ideia do cumprimento de sua função social. Há, portanto, o direito fundamental à propriedade em cumprimento de sua função social, conforme o Artigo $5^{\circ}$, XXII ("é garantido o direito de propriedade") e XXIII ("a propriedade atenderá à sua função social"). O mesmo entendimento fica claro com a leitura do artigo 170 da CF/88, ao incluir não só a propriedade (inciso II) como também o cumprimento de sua função social (inciso III) como princípios da ordem econômica brasileira. Não restam dúvidas, portanto, quanto a vinculação do direito de propriedade ao cumprimento de sua função social.

O grande embate em torno da regulamentação da Reforma Agrária no Brasil gerou um texto constitucional controverso e ambíguo. Enquanto o artigo 186 define os requisitos para cumprimento da função social como simultâneos, o artigo anterior torna insuscetível de desapropriação para fins de reforma agrária as propriedades produtivas, apenas um dos requisitos citados no artigo seguinte.

O artigo 186 da Constituição Federal define como requisitos simultâneos para o cumprimento da função social da propriedade: "I- aproveitamento racional e adequado; II- utilização adequada dos recursos naturais disponíveis e preservação do meio ambiente; III- observância das disposições que regulam as relações de trabalho; IV - exploração que favoreça o bem-estar dos proprietários e dos trabalhadores."

O caput do referido artigo não deixa dúvidas quanto à necessidade de cumprimento simultâneo dos requisitos determinados, mas, por conta da proibição de desapropriação de terras produtivas (art. 185, II), passou a ser a produtividade o único elemento observado na análise da função social, tanto pela jurisprudência quanto pelo INCRA. Nesse 
sentido, haveria, na prática, uma desconstrução da ideia de simultaneidade dos requisitos, bastando apenas a verificação de um deles, o aproveitamento racional e adequado da propriedade.

Para suprir essa dúvida, Eros Grau faz uso da interpretação sistemática da Constituição Federal, deixando claro que Constituição deve ser lida e interpretada como um conjunto completo, sendo impossível analisar uma parte sem a outra. É nesse sentido que se coloca sua célebre frase, reiteradamente citada em artigos acadêmicos sobre o tema: "Não se interpreta a Constituição em tiras, aos pedaços" (GRAU, 2001). Sobre a interpretação sistemática, cabe utilizar a elucidação feita por Adrian Sgarbi em sua Introdução à Teoria do Direito (SGARBI, 2013). Utilizando-se dessa técnica o intérprete deve buscar não as informações óbvias e literais do instrumento normativo como elemento isolado, mas observar todas as disposições do ordenamento de modo a buscar harmonia entre elas.

Não faria sentido, portanto, considerar que, a proibição feita pelo artigo 185, inciso II, fez cair por terra todo o instituto da função social da propriedade e a necessidade de leitura simultânea de seus requisitos. É necessário, por conseguinte, compreender a produtividade somente como um dos elementos para aferição de cumprimento da função social da propriedade.

Compreendendo a função social como elemento formador do conceito de propriedade e garantidor desse direito fundamental, assim como um princípio da ordem econômica brasileira, entende-se que os requisitos da função social devem ser avaliados como um todo, buscando a verificação do cumprimento de cada um deles, independentemente da produtividade. 


\section{REGULAMENTAÇÃO \\ INFRACONSTITUCIONAL DA \\ DESAPROPRIAÇÃO PARA FINS DE \\ REFORMA AGRÁRIA E OS ÍNDICES DE AFERIMENTO DA PRODUTIVIDADE}

Mesmo após a promulgação da Constituição Federal de 1988, muitos anos foram necessários para que se desse início ao programa de reforma agrária através das desapropriações. Tal fenômeno aconteceu por conta do atraso na edição de normas regulamentadores dos artigos da Constituição estudados anteriormente. Somente em 1993 foram promulgadas a Lei 8.629/93, regulamentando os dispositivos relativos à reforma agrária, e a Lei Complementar 76/93, dispondo sobre o procedimento para a Desapropriação para Fins de Reforma Agrária.

A Lei 8.629/93 traz em seu artigo $9^{\circ}$ os requisitos de cumprimento da função social da propriedade, repetindo os componentes listados na Constituição Federal. No parágrafo primeiro do referido artigo, é possível compreender que o aferimento do elemento da produtividade se dá quando a propriedade atinge os índices determinados do Grau de Utilização da Terra (GUT) e Grau de Eficiência na Exploração (GEE). É também na referida lei que estão indicados, no artigo $6^{\circ}$, os métodos para o cálculo dos graus citados.

Antes de discutir o que é fixado pelo artigo $6^{\circ}$ para definir se há produção racional e adequada na propriedade, é preciso refletir sobre a atualização dos índices para aferimento desse elemento de produtividade. O artigo 11 da Lei 8.629/93, correntemente estudada, determina de forma expressa o ajuste periódico dos índices "de forma a levar em conta o progresso científico e tecnológico da agricultura e o desenvolvimento regional". A mesma norma fixa o Ministério do Desenvolvimento Agrário e o Ministério da Agricultura como responsáveis por essa atualização, gerando um conflito histórico entre os dois ministérios que resultou na não atualização dos índices desde a Ditadura Militar. Nesse sentido, fica claro que o elemento da produtividade é 
extremamente defasado se for usado como único requisito de cumprimento da função social.

O proprietário contemporâneo, com todos os avanços tecnológicos já previstos pelo legislador, não enfrenta qualquer dificuldade para ter seu imóvel considerado produtivo, uma vez que os índices remontam à década de 1970. Portanto, se já havia um sólido questionamento sobre a função social da propriedade ser determinada somente pelo elemento da exploração racional (por conta da necessidade de avaliação simultânea dos requisitos com uma leitura sistemática da Constituição), a desatualização alarmante dos índices de produtividade se coloca como mais um obstáculo que enfraquece esse requisito como único a ser observado para desapropriação para fins de reforma agrária.

Voltando ao cálculo dos índices determinados pela Lei 8.629/93, são eles encontrados em seu artigo $6^{\circ}$. O caput do referido artigo deixa claro que é necessário que a produção racional e econômica atinja ambos os graus de aferimento da produtividade, Grau de Utilização da Terra (GUT) e Grau de Eficiência na Exploração (GEE), para que a propriedade seja considerada produtiva. Nesse sentido, são encontrados dois elementos para que uma propriedade seja produtiva: a exploração econômica e a exploração racional. A primeira está relacionada aos graus de utilização da terra e de eficiência da exploração, enquanto a segunda remonta aos outros elementos da função social da propriedade. É possível perceber que, mesmo em uma análise interna da produção, há uma interface entre os requisitos, não podendo ser eles compreendidos de forma isolada.

O cálculo do Grau de Utilização da Terra (GUT) é indicado no $\S 1^{\circ}$ do artigo $6^{\circ}$ da Lei 8.629/93, sendo necessário para seu aferimento a noção de área efetivamente utilizada, normatizada no $\S 3^{\circ}$. Tal necessidade se dá porque o cálculo do GUT é feito pela relação percentual entre a área efetivamente utilizada e a área total aproveitável, essa última sendo extraída a partir da noção de áreas não aproveitáveis, fixada no artigo 10 da lei correntemente estudada. Em suma, a partir da compreensão dos incisos do $\S 3^{\circ}$ chegamos a área efetivamente utilizada da propriedade, enquanto o artigo 10 determina as áreas não aproveitáveis e, a contrario senso, torna possível o cálculo da 
área total aproveitável. A partir do cálculo percentual entre a área efetivamente utilizada e área total aproveitável, o GUT deve ser igual ou superior a $80 \%$.

Para calcular o Grau de Eficiência na Exploração (GEE), é preciso fazer atenta leitura do $\S 2^{\circ}$ do artigo 6 , indicando em seus incisos a conta necessária para a produção vegetal e produção pecuária. 0 inciso III do referido dispositivo, indica que "a soma dos resultados obtidos na forma dos incisos I e II deste artigo, dividida pela área efetivamente utilizada e multiplicada por 100 (cem), determina o grau de eficiência na exploração", que deve ser igual ou superior a 100\% para que a propriedade seja considerada produtiva.

A partir da compreensão dos cálculos do Grau de Utilização da Terra (GUT) e Grau de Eficiência na Exploração (GEE) e do questionamento sobre a desatualização dos índices necessários para tal, o próximo passo é compreender se a produção aferida precisa levar em conta outros instrumentos normativos. Ou seja, é preciso refletir se os graus estudados podem sofrer interferência de outros elementos legais, garantindo que a produtividade seja atingida de forma lícita.

\section{CABIMENTO DE DESAPROPRIAÇÃO PARA FINS DE REFORMA AGRÁRIA NOS CASOS DE DESCUMPRIMENTO DAS FUNÇÕES AMBIENTAIS E TRABALHISTA}

O artigo $6^{\circ}$ da Lei 8.629/93, em seu $\S 3^{\circ}$, inciso III, ao tratar das áreas efetivamente utilizadas faz uma ressalva, dizendo ser necessário observar os índices de rendimento estabelecidos pelo órgão competente do Poder Executivo e a legislação ambiental. Não há dúvidas, porém, de que a legislação ambiental deve ser sempre respeitada, assim como a legislação trabalhista e todo o ordenamento jurídico brasileiro. Nesse sentido, fica claro que a produção na terra só pode ser considerada se for feita de forma lícita.

Por estarem os graus de utilização da terra e de eficiência na exploração (GUT e GEE) relacionados ao que a lei chama de exploração 
econômica, é necessário também voltar o olhar para a exploração racional. Tal relação se mostra necessária, como observado anteriormente, pois a avaliação da produtividade deve levar em conta ambos os aspectos da exploração. Os outros requisitos constitucionais para o cumprimento da função social da propriedade estariam também contidos dentro da definição de propriedade produtiva do caput do artigo $6^{\circ}$ da Lei 8.629/93.

A interpretação de que a propriedade produtiva deve ser analisada segundo sua exploração econômica e racional não decorre somente da leitura do artigo citado, mas também da compreensão de que não seria razoável que o legislador considerasse legítima qualquer produção que vai contra a legislação vigente.

Tendo em vista o conceito de exploração racional da propriedade produtiva e a simultaneidade dos requisitos para cumprimento da função social da propriedade, compreende-se a possibilidade de desapropriação para fins de reforma agrária de propriedades consideradas produtivas pelos graus de utilização da terra e de eficiência na exploração, mas em descumprimento do elemento da exploração racional e demais requisitos.

Em se tratando das desapropriações para fins de reforma agrária por conta de descumprimento da função social ambiental (artigo 186, II, CFl88), é importante analisar o artigo 225 da CF/88. No $\S 3^{\circ}$ há previsão expressa de sancionamento administrativo: "[a]s condutas e atividades consideradas lesivas ao meio ambiente sujeitarão os infratores, pessoas físicas ou jurídicas, a sanções penais e administrativas, independentemente da obrigação de reparar os danos causados."

Nesse sentido, a Constituição Federal fala de "sanções" administrativas, podendo ser aplicadas, portanto, mais de uma. Sendo a desapropriação para fins de reforma agrária considerada sanção administrativa por parte majoritária da doutrina, não há dúvidas de que é cabível a desapropriação nos casos de descumprimento da função social ambiental.

A interpretação que privilegia o impedimento da desapropriação de propriedades em descumprimento das funções ambientais e trabalhis- 
tas tem como consequência desastrosa de seu raciocínio considerar que o artigo 185, inciso II, pode prevalecer sobre todo o artigo $7^{\circ} \mathrm{da}$ Constituição, que trata dos direitos dos trabalhadores, e todo o Capítulo $\mathrm{VI}$, que trata do meio ambiente. É preciso atentar que o direito de propriedade não pode ser considerado absoluto, tampouco a produtividade deve servir como imunidade ao abuso do direito e condições ilícitas de exploração.

Nessa perspectiva, se encontra parecer técnico do INCRA de 2005 sobre o tema que atenta ao fato de que, considerar o impedimento do artigo 185 como garantia para propriedades produtivas em qualquer condição, mesmo em decorrência de ato ilícito ou abuso de direito, implicaria em "incentivo ao brocardo segundo o qual os fins justificam os meios, exigiria admitir a defesa da apologia do ilícito pela carta constitucional da nação, premissa inadmissível em qualquer regime" (PINTO JUNIOR e FARIAS, 2005).

Parece claro que, a partir de interpretação sistemática da Constituição Federal, os requisitos para cumprimento da função social da propriedade devem ser observados de forma simultânea. É também evidente que a propriedade produtiva se caracteriza por sua exploração econômica, relacionada aos graus de utilização da terra e de eficiência na exploração (GUT e GEE), e racional, relacionada aos demais elementos da função social (trabalhista, ambiental e bem-estar).

Conclui-se, portanto, que é possível aplicar a desapropriação-sanção prevista no artigo 184 da Magna Carta para propriedades consideradas produtivas pelos índices citados, quando há descumprimento dos demais requisitos, gerando ilicitudes e abusos de direito que afetam a dignidade dos trabalhadores e causam danos ao meio ambiente. Essa desapropriação poderia ocorrer seja pela aplicação direta dos demais requisitos simultâneos para cumprimento da função social da propriedade, seja por alteração nos índices de produtividade.

A alteração dos graus indicados na lei específica pode ocorrer pela influência da exploração racional na análise da exploração econômica. Sendo assim, não poderiam ser considerados pelos referidos graus as áreas que foram exploradas de forma ilícita. Por exemplo, se há vasta 
plantação de cana de açúcar sendo produzida a partir de trabalho escravo ou em violação de leis trabalhistas, essa produção não poderá ser considerada no GUT ou GEE, devendo ser proporcionalmente retirada dos cálculos.

Sobre a alteração dos graus por conta de produções ilícitas, utilizando-se do exemplo das áreas de pasto em área de preservação permanente (contrariando a legislação ambiental), Renata Almeida D'ávila defende que a produção em desconformidade com a legislação não pode ser considerada "efetivamente utilizada", devendo ser descontada do Grau de Eficiência na Exploração (GEE) (D’áVILA, 2011). Assim, a propriedade será considerada improdutiva, uma vez que não terá atingido o grau necessário para ser caracterizada como produtiva. A análise do cumprimento dos demais requisitos da função social pode funcionar para alterar os graus de aferimento da produtividade, podendo, por conseguinte, retirar a "imunidade" que seria conferida pelo artigo 185, inciso II.

No mesmo sentido caminha o já citado parecer técnico do INCRA intitulado "Função Social da Propriedade: Dimensões ambiental e trabalhista", que após criticar a interpretação limitadora que privilegia a vedação do art. 185 e a atual postura do INCRA e do poder judiciário que analisa somente o elemento da produtividade, tem como conclusão:

Diante do exposto e considerando o ordenamento jurídico vigente, nosso parecer alcança as seguintes conclusões:

a) Deflui da ordem jurídica positivada que no conceito de função social está contido o conceito de produtividade, mas que no conceito de produtividade também estão contidas parcelas dos conceitos de função ambiental, função trabalhista e função bem estar, isto é, que a função social é continente e conteúdo da produtividade.

b) A vedação do art. 185 da CFl88 não pode excepcionar ipso facto o comando do art. 184, senão nos casos em que a produtividade provenha de atividades não contrapostas a vedações legais, e, pois, não pode ser invocada para tutelar os casos em 
que a produtividade derive de descumprimento de preceitos de regime ambiental ou trabalhista, já que, em essência, esses ilícitos, além de impedirem o aperfeiçoamento da função social, viabilizam desincorporação dos ganhos de produtividade correspondentes, expondo o imóvel à desapropriação-sanção inclusive por improdutividade ficta, ou produtividade irracional.

c) No contrário sensu da expressão "exploração racional", preceituada no caput do art. $6^{\circ}$ da Lei $n^{\circ} 8.629193$ se desenham todas as situações de ilícito possíveis, e previstas em regimes jurídicos próprios, entre elas cada qual que vier a configurar vulneração dos incisos II a IV do art. 186 da CFI88, na tipificação a eles dada pelos parágrafos $2^{\circ}$ a $5^{\circ}$ do art. $9^{\circ}$ da Lei $n^{\circ} 8.629193$.

d) Em casos nos quais o descumprimento da função social da propriedade possa ser objetivável de plano e demonstrado por simples operação de conta e conferência, compete autonomamente ao órgão federal executor da política e reforma agrária proceder à objetivação, mediante fiscalização em que se assegure ao proprietário o devido processo legal administrativo.

e) Nos demais casos, compete ao órgão federal executor da política e reforma agrária, em conjunto com os demais órgãos executores da políticas conexas às funções ambiental e trabalhista, a elaboração de norma técnica e adoção de medidas administrativas conjuntas de fiscalização, com vistas a conferir efetividade às normas constitucionais previstas no art. 186 da CF।88, e incisos II a IV do art. 9ª da Lei $n^{\circ}$ 8.629193.

f) Nos casos das alíneas anteriores, a propriedade, embora produtiva do ponto de vista economicista, suscetibiliza-se à desapropriação-sanção de que cuida o art. 184 da Constituição Federal da República Federativa do Brasil, se flagrada como descumpridora das outras condicionantes da função social elencadas no art. 186, II, III e IV da CFI88, (II- utilização adequada dos recursos naturais disponíveis e preservação do meio ambiente; III- observância das disposições que regulam as relações de trabalho; IV- exploração que favoreça o bem-estar dos proprietários e dos trabalhadores). 


\section{ESTUDO DE CASO: FAZENDA NOVA ALEGRIA (MG) E CABACEIRAS (PA)}

Como referência para o estudo da desapropriação para fins de reforma agrária nos casos de descumprimento das funções ambiental e trabalhista, utilizamos como estudo de caso as fazendas Nova Alegria, localizada no município de Felisburgo, em Minas Gerais, e Cabaceiras, em Marabá, no Pará.

A Fazenda Cabaceiras foi o primeiro caso brasileiro de desapropriação para fins de reforma agrária justificada por descumprimento da função social trabalhista. A fazenda era propriedade de empresa da família Mutran, tradicional controladora da produção e exportação de castanha do pará desde a década de 1970. A empresa Jorge Mutran Exportação e Importação Ltda. comprou as terras da Fazenda Cabaceiras em 1989, mesmo ano em que compraram área anexa conhecida como Castanhal de Cabaceiras. Essa última era área de aforamento, destinada a extração de castanhas. Havia fortes dúvidas se a propriedade da empresa seria justa, podendo ser pertencente ao Estado do Pará (FREITAS, 2015).

A propriedade da Fazenda Cabaceiras era anteriormente (de 1983 a 1989) pertencente a Nelito Indústria e Comércio S.A., sendo utilizada para extração de castanha do pará. Porém, no mesmo ano em que foi vendida para Jorge Mutran Exportação e Importação Ltda. iniciou-se um processo de derrubada da mata com destinação da madeira ao comércio de exportação.

No ano de 1999, houve a primeira denúncia de trabalho escravo e a existência de um cemitério clandestino de trabalhadores no interior da propriedade, feito pela Revista Caros Amigos. A denúncia foi publicada pela revista em setembro de 1999 e, em março do mesmo ano, foi feita ocupação pelo MST na Fazenda. A empresa proprietária já havia ingressado com ação de interdito proibitório no ano anterior visando impedir a ocupação e teve liminar concedida sem oitiva da parte contrária. Com a entrada das famílias na terra, o advogado da empresa solicitou a conversão em ação de reintegração de posse e teve o pe- 
dido atendido. O advogado do MST argumentou, sem sucesso, serem pessoas diferentes aquelas objeto do interdito e as ocupantes atuais da fazenda, a propriedade injusta da fazenda, sendo terras públicas, e o fato da reintegração ser penosa para as famílias (FREITAS, 2015).

A partir daí foram feitos três reintegrações de posse na Fazenda Cabaceiras, sempre com o retorno dos ocupantes dias depois. No primeiro, oficiais de justiça foram à ocupação no dia 8 de abril de 1999 para notificar a ordem de reintegração e ao retornar no dia 24 do mesmo mês, a propriedade já estava desocupada por conta de acordo entre o INCRA, o MST e o Estado do Pará. O acordo visava a desocupação para permitir a vistoria na área, por conta de interpretação vigente na época que impedia a vistoria e a desapropriação de áreas ocupadas pelos movimentos sociais que reivindicam a terra (FREITAS, 2015).

No dia 10 de junho do mesmo ano foi realizada nova ocupação, alvo de ordem de desocupação concedida no dia 15 de junho. A ordem, porém, só foi cumprida no dia 26 de julho, quando a Polícia Militar fez operação para cumprir várias ordens de reintegração na região. No dia 30 de julho as famílias ocuparam o imóvel novamente. O proprietário então pediu o confisco do veículo de um dos ocupantes para servir de garantia pelos danos causados. O pedido foi negado, mas nova ordem de reintegração foi concedida.

A ação possessória se procrastinou até setembro de 2008, quando o INCRA ingressou com ação de desapropriação para fins de reforma agrária da Fazenda Cabaceiras argumentando pelo descumprimento da função social trabalhista por conta da utilização de trabalho escravo na propriedade. A violação flagrante aos direitos trabalhistas foi constatada em três ações do Ministério do Trabalho entre 2002 e 2004, quando foram resgatadas 82 pessoas trabaIhando em condições degradantes.

O Decreto Presidencial que declara de interesse social, para fins de reforma agrária, a Fazenda Cabaceiras foi publicado em 18 de outubro de 2004, possibilitando o ingresso de ação de desapropriação pelo INCRA. O decreto foi alvo de Mandado de Segurança pedindo efeito suspensivo no Supremo Tribunal Federal, foi concedida liminar favorá- 
vel à empresa, impedindo a ação de desapropriação. Porém, no dia $1^{\circ}$ de abril de 2008 a Jorge Mutran desistiu do Mandado de Segurança (MS 25260 DF).

No dia 26 de novembro de 2008, o juiz da Vara Federal de Marabá imitiu o INCRA na posse do imóvel, possibilitando o início do assentamento rural na fazenda, nomeado de Assentamento 26 de Março, onde foram assentadas mais de duzentas famílias. Permaneceu na justiça o embate sobre os valores da indenização pela desapropriação.

O embate jurídico relacionado a Fazenda Cabaceiras deu início com uma ocupação classificada como simbólica pelo MST, uma vez que era prática do movimento no Pará a opção por ocupar fazendas de proprietários locais identificados por práticas clientelísticas e paternalistas (FREITAS, 2015). Termina o conflito também de maneira simbólica, consolidando o entendimento de necessidade de cumprimento simultâneo dos requisitos da função social, permitindo a desapropriação da terra, uma vez que teve a produtividade gerada por trabalho em desconformidade com as normas trabalhistas.

A Fazenda Nova Alegria, em Minas Gerais, foi o caso escolhido para estudar a suscetibilidade de desapropriação para fins de reforma agrária de fazendas que descumprem a legislação ambiental. A referida fazenda foi a primeira propriedade declarada em Decreto Presidencial passível de desapropriação por descumprimento da função social ambiental da propriedade. O decreto foi publicado em 19 de agosto de 2009. Famílias já ocupavam a fazenda desde maio de 2002.

A fazenda era de propriedade de Adriano Chafik e teve laudo de vistoria realizado pelo INCRA em 2006. O laudo atestava a produtividade da propriedade, com exploração predominante da pecuária, mas declarava o descumprimento da função social ambiental da propriedade por conta da utilização de toda a Área de Preservação Permanente (APP) para criação de gado. Também foi fundamental para caracterização de descumprimento da função social o episódio que ficou conhecido como "Chacina de Felisburgo", quando à mando do proprietário cinco acampados foram assassinados e mais de dez foram feridos em novembro de 2004. 
Nesse sentido, a vistoria do INCRA atestava em seu laudo a produtividade da fazenda (art. 186, inciso I) e o respeito às normas trabaIhistas (art. 186, inciso III), mas questionava o respeito às normas ambientais (art. 186, inciso II) e ao bem-estar social, por conta do conflito existente na terra (art. 186, inciso IV).

O imbróglio envolvendo a Fazenda Nova Alegria foi responsável por uma série de ações na justiça: a ação de desapropriação movida pela autarquia federal responsável após o decreto presidencial ${ }^{5}$, ação movida pelo proprietário pedindo a nulidade do procedimento administrativo que resultou no decreto presidencial ${ }^{6}$, ação de reintegração de posse movida pelo proprietário contra os ocupantes, ação discriminatória ajuizada pelo Estado de Minas Gerais visando apurar e retomar a gleba devoluta da fazenda e ações judiciais de natureza criminal por conta da Chacina de Felisburgo.

O juiz federal de primeira instância concedeu liminar de suspensão do procedimento administrativo de desapropriação conduzido pelo INCRAIMG em dezembro de 2007, sob a argumentação de que a produtividade da fazenda a imuniza da desapropriação para fins de reforma agrária, mesmo que não sejam atendidos todos os requisitos da função social da propriedade. Em 2008, foi mantida a decisão da primeira instância pelo Tribunal Regional Federal da $1^{\text {a }}$ Região ao apreciar recurso do INCRA, visando a desobstrução do procedimento administrativo. $O$ INCRA então recorreu ao Superior Tribunal de Justiça e ao Supremo Tribunal Federal e ambos mantiveram a suspensão do processo, sendo suas decisões finais proferidas apenas em 2011 e 2012.

Antes das decisões do STJ e STF, o INCRAIMG ingressou com nova ação judicial, de natureza cautelar, em novembro de 2008 direcionada ao desembargador presidente do Tribunal Regional Federal da $1^{\mathrm{a}} \mathrm{Re}-$ gião, que concedeu a medida liminar pedida ${ }^{7}$. Foi então permitido ao INCRA dar continuidade ao procedimento administrativo de desapropriação da Fazenda Nova Alegria, culminando no decreto presidencial

5 Processo $n^{\circ}$ 2009.38.00.032320-2. <www.jfmg.jus.br>. Acessado em julho de 2015.

6 Processo $n^{\circ}$ 2007.38.00.037767-3. <www.jfmg.jus.br>. Acessado em julho de 2015.

7 Processo $n^{\circ}$ 2008.01.00.065297-0/MG - TRF-1 
em 2009, declarando a propriedade como passível de desapropriação para fins de reforma agrária, diante do descumprimento das funções social, ambiental e de bem estar, por conta do conflito agrário.

A ação judicial de desapropriação da Fazenda Nova Alegria teve início em dezembro de 2009. O pedido liminar de imissão do INCRA na posse da fazenda teve apreciação somente três meses depois do ingresso da ação, sendo indeferido. É importante salientar que a Lei Complementar 76/93 determina o prazo de 48 horas a partir do ingresso da ação de desapropriação para a imissão da autarquia na posse do imóvel. Há, portanto, clara violação do prazo legal no caso em tela. A justificativa do magistrado foi a ainda pendente ação de nulidade do procedimento administrativo, gerando seu entendimento de que a imissão na posse poderia ser precipitada. O processo desapropriatório ficou suspenso até decisão final da referida ação.

Em abril de 2010, o INCRA/MG recorreu ao Tribunal Federal da $1^{\text {a }}$ Região. Mas, em junho de 2010, o Tribunal negou o pedido liminar para prosseguimento da ação de desapropriação. O mérito do recurso foi julgado pelo Tribunal em janeiro de 2011, mantendo a suspensão do processo até o julgamento da ação de nulidade do procedimento administrativo. Em ambas as decisões, o Tribunal argumentou que os conflitos agrários e o desrespeito às normas ambientais não afastam a impossibilidade de desapropriação de propriedades produtivas. Fica clara a identificação do Poder Judiciário com a interpretação refutada no presente trabalho, afirmando que a propriedade produtiva é insuscetível de desapropriação, mesmo em descumprimento das demais funções sociais.

Após essas decisões, as ações ficaram suspensas. A ação de desapropriação da Fazenda Nova Alegria, fundada no Decreto Presidencial de 2009, estava suspensa em função da ação de nulidade movida pelos proprietários da fazenda. Enquanto a ação de nulidade estava também suspensa aguardando a decisão de recursos sobre medidas liminares (antecipação de tutela).

Até que, em novembro de 2014, foi julgado procedente o pedido de anulação do procedimento administrativo do INCRA/MG e todos 
os atos subsequentes. Há duvidas sobre a consequência da decisão, uma vez que a competência para questionar o Decreto Presidencial seria do STF. A decisão do Tribunal Regional Federal $1^{a}$ Região ainda é passível de recursos.

A sentença judicial demonstrou clara filiação a interpretação de que o artigo 185 gera uma imunidade da propriedade produtiva, ficando essa protegida mesmo desrespeitando as legislações ambientais. Segue parte da sentença proferida pela juíza substituta da $12^{\mathrm{a}}$ Vara Federal ${ }^{8}$ :

É dizer que, a infração às normas ambientais não sujeita a propriedade à ação de desapropriação para fins de reforma agrária, pois a produtividade do imóvel, atestada pelo próprio INCRA, por si só, o imuniza da desapropriação por interesse social para fins de reforma agrária, mesmo que não sejam atendidos todos os requisitos relativos à sua função social.

Quanto a situação de tensão social vivida na propriedade, ensejando descumprimento do artigo 186, IV e, portanto, o descumprimento da função social que busca uma exploração da propriedade que favoreça o bem-estar dos proprietários e trabalhadores, a sentença repete a compreensão de imunidade da propriedade diante de sua produtividade. A juíza lembra ainda a ocasião de morte de cinco ocupantes da fazenda, mas se utiliza da ocupação para argumentar que a "invasão" da propriedade justifica o descumprimento da função social por força maior $^{9}$. É citada, ainda, a MP n 2.183-56/01, para classificar a ocupação como impedidora da ação desapropriatória.

8 Processo N ${ }^{\circ}$ 0037008-48.2007.4.01.3800 (Número antigo: 2007.38.00.037767-3) - $12^{a}$ VARA FEDERAL.

9 É preciso diferenciar o termo "ocupação" e "invasão". Ocupação se caracteriza pelo direito legítimo da população de pressionar o poder público a aplicação de garantias constitucionais e máxima efetivação da Constituição Federal, é parte do Estado Democrático de Direito. Invasão, por outro lado, se configura como crime de esbulho possessório, sendo enxergado como um ato ilegítimo, ilegal e violento. 
A conclusão do INCRA chega a ser um frontal descumprimento ao que prevê o art. $2^{\circ}, \S 6^{\circ}$, da Lei 8.629/93, na redação dada pela MP $n^{\circ} 2.183-56 / 01$, que proíbe a desapropriação de imóvel rural objeto de esbulho possessório ou invasão motivada por conflito agrário ou fundiário, nos dois anos seguintes à sua desocupação, ou no dobro de tempo, em caso de reincidência.

Cabe salientar que a interpretação feita atualmente pelo STF difere da utilizada pela juíza em sua sentença, que se filia a Súmula 354 do STJ. O Supremo Tribunal Federal tem interpretação consolidada de que é necessário haver nexo causal entre o estado de improdutividade da propriedade e a ocupação para haver incidência do artigo. Há ainda o entendimento de que se a ocupação for feita num pequeno espaço da propriedade e por curto período de tempo, não há caracterização de impedimento na realização da vistoria e demais atos do procedimento administrativo e, por conseguinte, da posterior ação desapropriatória. Segue jurisprudência que afirma a interpretação corrente do STF.

\section{EMENTA: Desapropriação para reforma agrária: validade.}

1.Decreto 2250/97: proibição de vistoria preparatória da desapropriação enquanto não cessada a ocupação do imóvel por terceiros: inaplicabilidade, à vista da omissão da portaria do INCRA, que the fixasse os termos e condições de aplicação. 2. Improdutividade do imóvel rural - de bucólica virgindade, mal bulida pelos arrendatários - que seria risível atribuir, a título de força maior, à ocupação por "sem terras", uma semana antes da vistoria, de fração diminuta do latifúndio. (STF, MS 23.054/PB. Tribunal Pleno, Relator Ministro SEPÚLVEDA PERTENCE. Julgado em 15/06/2000, publicado no DJ em 04/05/2001)

A alegação de que a vistoria não poderia ter sido feita, por afronta ao art. $2^{\circ}, \S 6^{\circ}$, da Lei $n^{\circ} 8.629 / 93$, fica afastada pelo acordo judicial e pelo fato de não vigorar, quando o imóvel foi invadido, em 12.10.1.999, a proibição de desapropriação nos dois anos seguintes à invasão. A invasão de menos de $1 \%$ do imóvel (20 hectares de um total de $\mathbf{2 . 4 2 0}$ hectares) não justifica, no caso, seu estado de improdutividade do imóvel. (MS 23.054- 
PB, rel. o Min. SEPÚLVEDA PERTENCE) A não apreciação da impugnação administrativa e violação aos princípios da ampla defesa e do contraditório, são refutadas pelos documentos apresentados pela autoridade impetrada. Segurança denegada. (STF, MS 23.857/MS. Tribunal Pleno, Relatora Ministra ELLEN GRACIE NORTHFLEET. Julgado em 23/04/2003, publicado no DJ em 13/06/2003)

EMENTA: CONSTITUCIONAL. AGRÁRIO. MANDADO DE SEGURANÇA. DESAPROPRIAÇÃO. REFORMA AGRÁRIA. NOTIFICAÇÃO DO PROPRIETÁRIO. AVISO DE RECEBIMENTO. ASSINATURA. EMPREGADO COM PODERES OUTORGADOS POR PROCURAÇÃO. DILAÇÃO PROBATÓRIA. IMPOSSIBILIDADE DE APRECIAÇÃO EM MANDADO DE SEGURANÇA. ESBULHO POSSESSÓRIO POSTERIOR À VISTORIA. INAPLICABILIDADE DO ART. $2^{\circ}, \S 6^{\circ}$, DA LEI N. 8.629/93. COMPOSIÇÃO NA AÇÃO DE REINTEGRAÇÃO DE POSSE. DESCARACTERIZAÇÃO DA INVASÃO. PRODUTIVIDADE DO IMÓVEL. DILAÇÃO PROBATÓRIA. APRECIAÇÃO EM MANDADO DE SEGURANÇA. IMPOSSIBILIDADE. (...) 3. 0 esbuIho possessório que impede a desapropriação [art. $2^{\circ}, \S 6^{\circ}$, da Lei n. 8.629/93, na redação dada pela Medida Provisória n. 2.183/01], deve ser significativo e anterior à vistoria do imóvel, a ponto de alterar os graus de utilização da terra e de eficiência em sua exploração, comprometendo os índices fixados em lei. Precedente [MS n. 23.759, Relator o Ministro CELSO DE MELLO, DJ 22.08.2003]. (STF, MS 25.360/ DF. Tribunal Pleno, Relator Ministro EROS GRAU. Julgado em 27/10/2005, publicado no DJ em 25/11/2005, grifos do original)

Em maio de 2015 foi recebida apelação interposta pelo INCRAI MG na ação de anulação do processo administrativo, que ainda não foi julgada. Em janeiro de 2015 foi julgada extinta sem resolução de mérito a ação de desapropriação da Fazenda Nova Alegria, diante da anulação do procedimento administrativo no processo movido pelo proprietário. Em maio de 2015 foi recebida apelação do INCRA/MG na ação de desapropriação.

No caso da Fazenda Cabaceiras, a utilização de trabalho escravo tornou a propriedade suscetível de desapropriação para fins de refor- 
ma agrária por descumprimento da função social trabalhista. Mesmo com a resistência do proprietário, o INCRA e as famílias ocupantes foram bem sucedidas na ação de desapropriação, possibilitando a imissão da autarquia na posse da fazenda e dando início ao Assentamento 26 de Março. Por outro lado, a Fazenda Nova Alegria ainda se apresenta como um desafio, com imbróglios judiciais ainda não resolvidos. Ficou demonstrada a violação da legislação ambiental, configurando descumprimento da função social ambiental, e a violência utilizada contra os ocupantes da fazenda, em descumprimento da função social de bem estar. No entanto, o proprietário conseguiu a anulação do procedimento administrativo realizado pelo INCRA, o que ensejou a extinção do processo de desapropriação sem resolução do mérito. Ambos os processos ainda estão em andamento e os recursos já foram recebidos.

\section{CONCLUSÕES}

A concentração fundiária é um problema antigo no Brasil. A grande quantidade de latifúndios improdutivos gera profundas desigualdades sociais, falta de acesso à emprego e terra, ineficiência na produção alimentar e inchaço dos grandes centros urbanos. Nesse sentido, o debate sobre a Reforma Agrária não envolve somente a questão rural, mas também as consequências para a alimentação e organização das cidades.

A desapropriação para fins de reforma agrária é uma forma de sanção aos proprietários que descumprem a função social da propriedade, conferindo a terra novos beneficiários que passam a utilizá-la conforme a Constituição Federal. Nesse sentido, é fundamental que a simultaneidade dos requisitos da função social seja observada. Não pode ser a produtividade avaliada de forma puramente economicista uma forma de imunizar o proprietário violador da Constituição.

A tese defendida no presente trabalho e fruto da pesquisa é, portanto, de que a propriedade deve cumprir a sua função social, avaliada pela observância de todos os requisitos determinados no art. 186. A avaliação da produtividade é somente um dos elementos a serem 
cumpridos pelo proprietário e não pode se sobrepor ao descumprimento dos demais requisitos.

Conforme o art. 184, a União deve desapropriar para fins de reforma agrária os imóveis que descumprem a sua função social através de ação de desapropriação autorizada por decreto que declara o imóvel como de interesse social para fins de reforma agrária.

De acordo com o art. $6^{\circ}$ da Lei 8.629/93, é produtiva a propriedade explorada racional e economicamente. O elemento econômico está relacionado aos graus de utilização da terra e de eficiência na exploração (GUT e GEE), enquanto o elemento racional se refere aos demais requisitos de cumprimento da função social. Considera-se produção racional, por conseguinte, aquela que não é decorrente de práticas ilícitas ou de abuso de direito.

Nesse sentido, a propriedade violadora de normas ambientais e trabalhistas está em descumprimento da sua função social e é, portanto, suscetível a desapropriação-sanção, como demonstram os casos da Fazenda Cabaceiras, no Pará, e Nova Alegria, em Minas Gerais.

No entanto, a interpretação sistemática da Constituição, geradora da compreensão de necessidade de leitura simultânea dos requisitos e que refuta a ideia de imunidade da propriedade produtiva, ainda não é majoritariamente reconhecida na jurisprudência brasileira.

A aplicação do art. 186 de forma ampla ainda se apresenta como um desafio ao Poder Judiciário e se mostra como importante estudo a ser realizado na continuidade da pesquisa.

É possível concluir pela pesquisa feita que a desapropriação-sanção de imóveis rurais em descumprimento de qualquer elemento da função social da propriedade é dever da União. A violação da legislação trabalhista e ambiental configura descumprimento dos requisitos da função social da propriedade e, portanto, ensejam a desapropriação para fins de reforma agrária. 


\section{REFERÊNCIAS}

BRUNO, Regina. Senhores da terra, senhores da guerra. Rio de Janeiro: Forense Universitária, 1997.

DáVILA, Renata Almeida. A desapropriação por descumprimento da função socioambiental da propriedade:prática administrativa e avanços jurisprudenciais. Âmbito Jurídico, Rio Grande, XIV, n. 91, ago 2011. Disponível em: <http://www.ambitojuridico.com.br/site/?n_link=revista_ artigos_leitura\&artigo_id=10162>. Acesso em: 10/04/2016.

FREITAS, EmmanuelOguri. As Representações Sociais da Propriedade da Terra em uma Ação Possessória no Sudeste do Pará: Embates de provas e argumentos entre MST e proprietário. Disponível em: <http:// publicadireito.com.br/artigos/?cod=5bf30c6aad7adf06>. Acesso em: 10/04/2016.

GRAU, Eros Roberto. A Ordem Econômica na Constituição de 1988. São Paulo: Malheiros, 2001.

G1 - GLOBO. "Desmatamento na Amazônia cresce 215\% em um ano, segundo o Imazon". Disponível em: <http://g1.globo.com/jornal-nacional/noticia/2015/03/desmatamento-na-amazonia-cresce-215-em-um-ano-segundo-o-imazon.html >. Acesso em 08/04/2016.

MARTINS, José de Souza. Militarização da Questão Agrária. Rio de Janeiro: Vozes, 1984.

PILATTI, Adriano. A Constituinte de 1987-1988: Progressistas, Conservadores, Ordem Econômica e Regras do Jogo. Rio de Janeiro: Lumen Juris, 2008.

PINTO JUNIOR, J. M.; FARIAS, V. A. Função Social da Propriedade: Dimensões Ambiental e Trabalhista. Brasília: Núcleo de Estudos Agrários e Desenvolvimento Rural, 2005.

RODRIGUES, Vera Lucia G. da Silva; SILVA, José Gomes da, "Conflitos de terras no Brasil”. In Reforma Agrária, n. 3-4, março-abril de 1975, e n.1, janeiro-fevereiro de 1977. 
SGARBI, Adrian. Introdução a Teoria do Direito. São Paulo: Marcial Pons, 2013.

SILVA, José Afonso. Curso de Direito Constitucional Positivo. $37^{\text {a }}$ Edição. São Paulo: Malheiros, 2014.

O GLOBO."Libertações por trabalho escravo na área urbana superam as do campo". Disponível em: <http://g1.globo.com/brasil/noticia/2014/02/libertacoes-por-trabalho-escravo-na-area-urbana-superam-do-campo.html>. Acesso em 08/04/2016. 